\title{
Variscan sourcing of Westphalian (Pennsylvanian) sandstones in the Canonbie Coalfield, UK
}

\author{
ANDREW MORTON* ${ }^{*}$, MARK FANNING $\ddagger \& N E I L$ JONES $\S$ \\ *HM Research Associates, 2 Clive Road, Balsall Common, West Midlands CV7 7DW, UK \\ †CASP, Department of Earth Sciences, University of Cambridge, 181a Huntingdon Road, Cambridge CB3 0DH, UK \\ $\ddagger$ Research School of Earth Sciences, The Australian National University, Canberra, ACT 0200, Australia \\ $\S$ British Geological Survey, Keyworth, Nottingham NG12 5GG, UK
}

(Received 10 April 2009; accepted 2 December 2009; First published online 12 February 2010)

\begin{abstract}
The zircon age spectrum in a sample from the Canonbie Bridge Sandstone Formation (Asturian) of southern Scotland contains two main peaks. One is Early Carboniferous in age (348$318 \mathrm{Ma}$ ), and corresponds to the age of igneous activity during the Variscan Orogeny. The other is of late Neoproterozoic to early Cambrian age (693-523 Ma), corresponding to the Cadomian. Together, these two groups comprise $70 \%$ of the zircon population. The presence of these two peaks shows unequivocally that a significant proportion of the sediment was derived from the Variscides of western or central Europe. The zircon population also contains a range of older Proterozoic zircons and a small Devonian component. These could have been derived from the Variscides, but it is possible that some were locally derived through recycling of northerly derived sandstones of Devonian-Carboniferous age. The zircon age data confirm previous suggestions of Variscide sourcing to the Canonbie area, made on the basis of petrographical, heavy mineral and palaeocurrent evidence, and extend the known northward distribution of Variscan-derived Westphalian sediment in the UK.
\end{abstract}

Keywords: zircon, provenance, Asturian, southern Scotland, Variscides.

\section{Introduction}

The Canonbie area of southwest Scotland (Fig. 1) is one of the few areas in the UK outside of the English Midlands where uppermost Carboniferous (BolsovianAsturian) strata can be directly examined at outcrop. The presence of red strata (including both primary and secondary red beds) in the 'Upper Coal Measures' of the Canonbie area was noted by Peach \& Horne (1903), Simpson \& Richey (1936), Barrett \& Richey (1945), Trotter (1953), Lumsden et al. (1967), Day (1970) and Picken (1988). Recent work by Jones, Holliday \& McKervey (2010) on outcrops along the River Esk (Fig. 2) has shown that these strata can be assigned to the Warwickshire Group because the redbed facies show evidence for early oxidation (primary reddening). The type area of the Warwickshire Group is the Warwickshire Coalfield in central England (Fig. 1), where the succession attains its fullest thickness of $1225 \mathrm{~m}$ (Powell et al. 2000) and typically comprises red mudstones and sandstones, with varying amounts of pebbly sandstone, conglomerate, grey mudstone, thin coals, lacustrine limestone ('Spirorbis limestone') and calcrete palaeosols. The Warwickshire Group ranges in age from late Bolsovian to Autunian, although the degree of biostratigraphical control is reduced compared with the Pennine Coal Measures Group

\footnotetext{
* Author for correspondence: a.c.morton@heavyminerals.fsnet. co.uk

$\S$ Present address: Saudi Aramco, P.O. Box 2001, Dhahran 31311, Saudi Arabia
}

because of the effects of reddening (Besly \& Cleal, 1997; Powell et al. 2000).

The Warwickshire Group in the Canonbie area has been subdivided into three formations (Jones, Holliday \& McKervey, 2010): the Eskbank Wood at the base, the Canonbie Bridge Sandstone, and the Becklees Sandstone at the top (Fig. 3). The Canonbie Bridge Sandstone Formation is noteworthy because of the occurrence of thick units of mediumand coarse-grained cross-bedded channel sandstones deposited by a series of northward-flowing braided river systems. The sandstones in the Canonbie Bridge Sandstone Formation are commonly micaceous and contain abundant lithic grains, thereby resembling the Halesowen Formation of central England and the Pennant Sandstone Formation of South Wales and southern England (Jones, Holliday \& McKervey, 2010), which are known from isotopic studies to represent detritus sourced from the Variscan orogenic belt to the south (Hallsworth et al. 2000; Sherlock, Jones \& Jones, 2000). The similarity between the Canonbie Bridge Sandstone Formation and the Halesowen Formation is substantiated by heavy mineral and garnet geochemical data (Jones, Holliday \& McKervey, 2010). The similarities in petrographical and heavy mineral characteristics between the Canonbie Bridge Sandstone Formation, the Halesowen Formation and the Pennant Sandstone Formation, together with evidence for northerly directed palaeocurrents, led Jones, Holliday \& McKervey (2010) to propose that the Canonbie Bridge sandstones represent the products of a river system that drained the Variscides several hundreds 


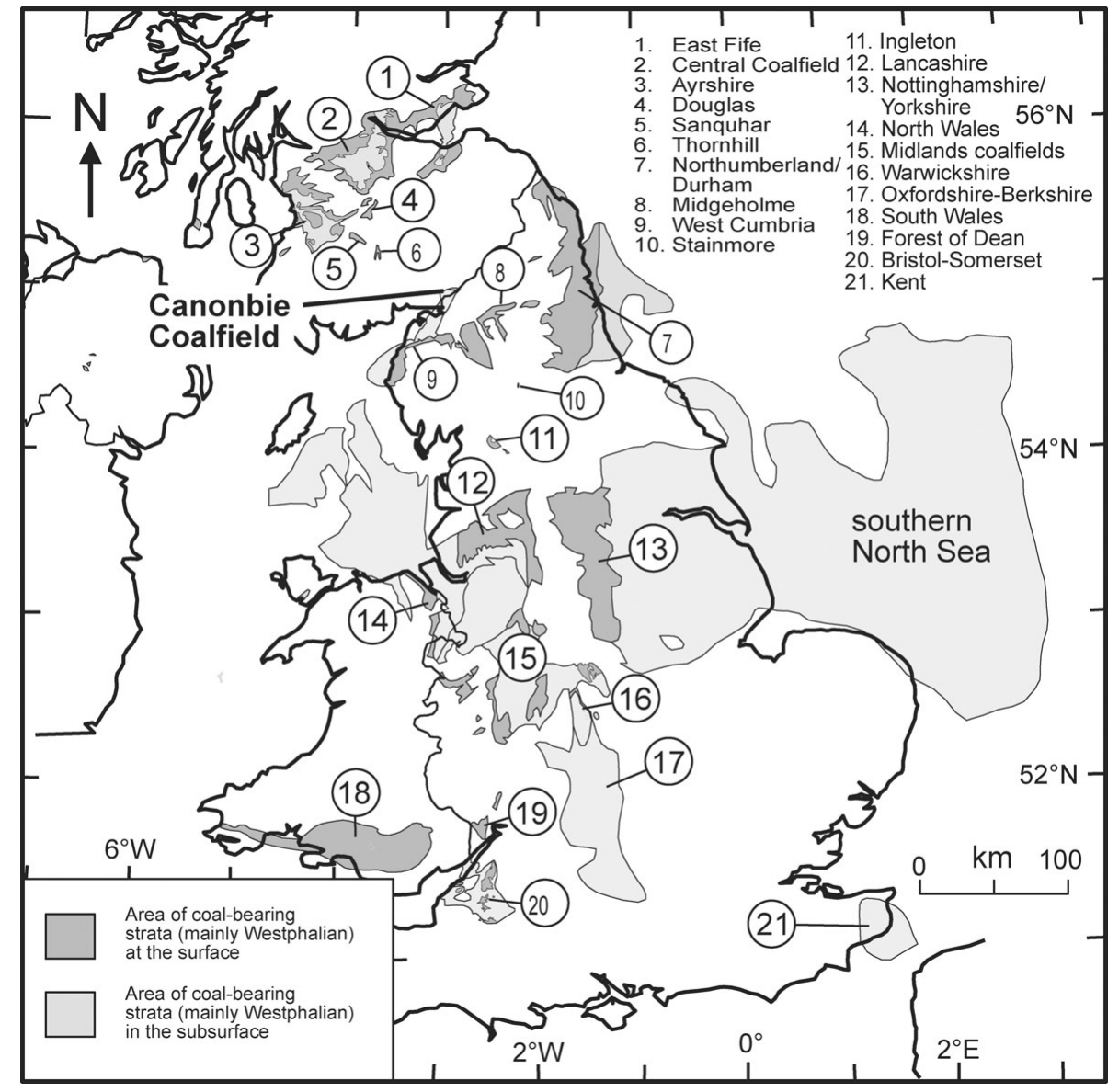

Figure 1. Location map showing the Canonbie Coalfield in relation to other UK coalfields (modified from British Geological Survey, 1999).

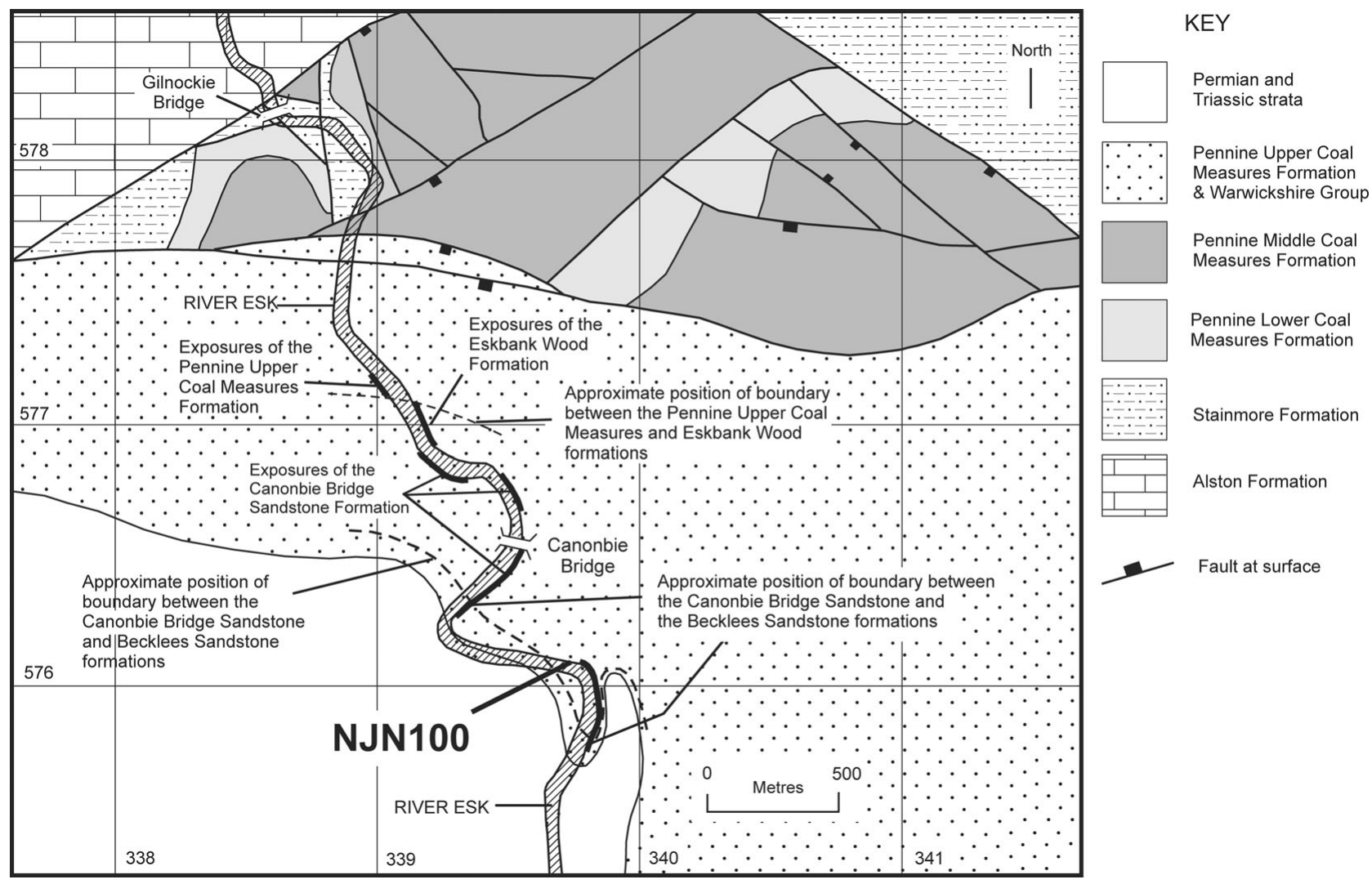

Figure 2. Geological map of the outcrops along the River Esk, Canonbie area, southern Scotland, showing the location of sample NJN100 (modified from Jones, Holliday \& McKervey, 2010). 


\begin{tabular}{|c|c|c|c|c|c|c|}
\hline \multicolumn{2}{|c|}{ CHRONOSTRATIGRAPHY } & \multicolumn{2}{|c|}{ LITHOSTRATIGRAPHY } & \multirow{2}{*}{$\begin{array}{l}\text { NON-MARINE } \\
\text { BIVALVE } \\
\text { ZONES }\end{array}$} & \multirow{2}{*}{$\begin{array}{l}\text { MAIN MARINE } \\
\text { BANDS }\end{array}$} & \multirow{2}{*}{$\begin{array}{l}\text { KEY MARKER BEDS } \\
\text { IN CANONBIE AREA }\end{array}$} \\
\hline $\begin{array}{l}\text { REGIONAL } \\
\text { STAGE }\end{array}$ & $\begin{array}{l}\text { REGIONAL } \\
\text { SUBSTAGE }\end{array}$ & GROUP & FORMATION & & & \\
\hline ?Stephanian & ?Cantabrian & \multirow[b]{2}{*}{ Warwickshire } & Becklees & \multirow{3}{*}{ prolifera } & & \multirow[b]{2}{*}{ High Coal } \\
\hline \multirow{7}{*}{ Westphalian } & Asturian & & $\begin{array}{l}\text { Sandstone } \\
\text { Canonbie Bridge } \\
\text { Sandstone } \\
\text { Eskbank Wood }\end{array}$ & & & \\
\hline & \multirow[t]{2}{*}{ Bolsovian } & \multirow{6}{*}{$\begin{array}{l}\text { Pennine } \\
\text { Coal } \\
\text { Measures }\end{array}$} & $\begin{array}{l}\text { Pennine Upper } \\
\text { Coal Measures }\end{array}$ & & \multirow{3}{*}{$\begin{array}{l}\text { - Cambriense - } \\
\text { - Aegiranum }\end{array}$} & \multirow{6}{*}{$\begin{aligned} &= \text { Riddings } \\
&= \text { Skelton } \\
& \text { Archerbeck Coal } \\
& \text { Nine Foot Coal } \\
&=\text { Queenslie/Solway }\end{aligned}$} \\
\hline & & & \multirow{3}{*}{$\begin{array}{l}\text { Pennine Middle } \\
\text { Coal Measures }\end{array}$} & U. similis-pulchra & & \\
\hline & Duckmantian & & & $\begin{array}{c}\text { Lower } \\
\text { similis-pulchra }\end{array}$ & & \\
\hline & \multirow{3}{*}{ Langsettian } & & & modiolaris & \multirow[t]{3}{*}{ - Vanderbeckei - } & \\
\hline & & & \multirow{2}{*}{$\begin{array}{l}\text { Pennine Lower } \\
\text { Coal Measures }\end{array}$} & communis & & \\
\hline & & & & lenisulcata & & \\
\hline \multirow[t]{2}{*}{ Namurian } & \multirow{2}{*}{$\begin{array}{l}\text { Pendleian } \\
\text { to } \\
\text { Yeadonian }\end{array}$} & \multirow[t]{2}{*}{ Yoredale } & Stainmore & & & \\
\hline & & & Alston & & C. leion & Catsbit (=Great) Lst \\
\hline
\end{tabular}

Figure 3. Lithostratigraphy of the Carboniferous in the Canonbie area, based on Trueman \& Weir (1946), Ramsbottom et al. (1978) and Waters et al. (2007).

of kilometres to the south. If so, this would extend the known northward distribution of Variscan-derived Upper Carboniferous sediment, the previous record being the Dalton Rock (Bolsovian) near Sheffield, Yorkshire (Hallsworth et al. 2000).

Although the evidence is compelling, the similarity in petrographical and mineralogical characteristics between the Canonbie Bridge Sandstone Formation and known Variscan-sourced sandstones in central and southern England is not absolute proof that these sandstones have a common provenance. In this paper, we report $\mathrm{U}-\mathrm{Pb}$ isotopic age dates of detrital zircons from a Canonbie Bridge Sandstone Formation sample, analysed in order to test the possibility that Variscansourced sediment reached the Canonbie area during Late Carboniferous times.

\section{Geological background}

Sedimentological and stratigraphical studies of the Warwickshire Group crop out along the River Esk (Fig. 2), together with borehole records from the Canonbie area, led Jones, Holliday \& McKervey (2010) to subdivide the group into three units: the Eskbank Wood, Canonbie Bridge Sandstone and Becklees Sandstone formations (Fig. 4).

The Eskbank Wood Formation consists mostly of red mudstones, interbedded with fine- to medium-grained sandstones, calcrete palaeosols, thin beds of Spirorbis limestone and Estheria-bearing mudstones. Sparse thin coals (some of which have been oxidized and altered to limestone) and grey mudstones are present in the lower part of the formation. The outcrop includes mudstones that contain a fauna believed to diagnose the $A$. tenuis or A. prolifera non-marine bivalve zones of Trueman \&
Weir (1946), indicative of an Asturian age (Fig. 3). The outcrop section along the River Esk (Fig. 2) proves up to $75 \mathrm{~m}$ of the formation, but borehole records suggest that the thickness of the formation ranges between 145 and $175 \mathrm{~m}$. The base of the formation, which is not exposed at outcrop and has therefore been defined in boreholes, is taken at the first major primary red-bed strata overlying the grey mudstones that dominate the Pennine Upper Coal Measures Formation (Fig. 3).

The overlying Canonbie Bridge Sandstone Formation is dominated by reddish brown to greenish grey, moderately to poorly sorted, fine- to coarsegrained sandstones with a lithic arenite composition, interbedded with reddish brown mudstones and reddish brown mudstone palaeosols (including calcretes). The sandstones occur as sharp to erosively based, crossbedded channel bodies, $10-30 \mathrm{~m}$ thick, in multistorey successions. In hand specimen, the sandstones are commonly micaceous and contain a noticeable component of greenish grey grains. Thin-section petrography reveals that the greenish grey grains are lithic clasts, mainly comprising fine foliated or schistose low-grade metapelitic and metapsammitic fragments. The formation is well exposed along the River Esk between $\sim 250 \mathrm{~m}$ south and $\sim 600 \mathrm{~m}$ north of Canonbie Bridge (Fig. 2). Borehole records show that the formation ranges in thickness from 131 to $168 \mathrm{~m}$. The sample reported in this paper (NJN100) was taken at [339789 576088] (Fig. 2).

The Becklees Sandstone Formation comprises sandstones with a subfeldspathic arenite composition, interbedded with reddish brown mudstones and reddish brown mudstone palaeosols (including calcretes). The sandstones are generally cross-bedded and occur as erosively based channel bodies, $10-30 \mathrm{~m}$ thick, in 


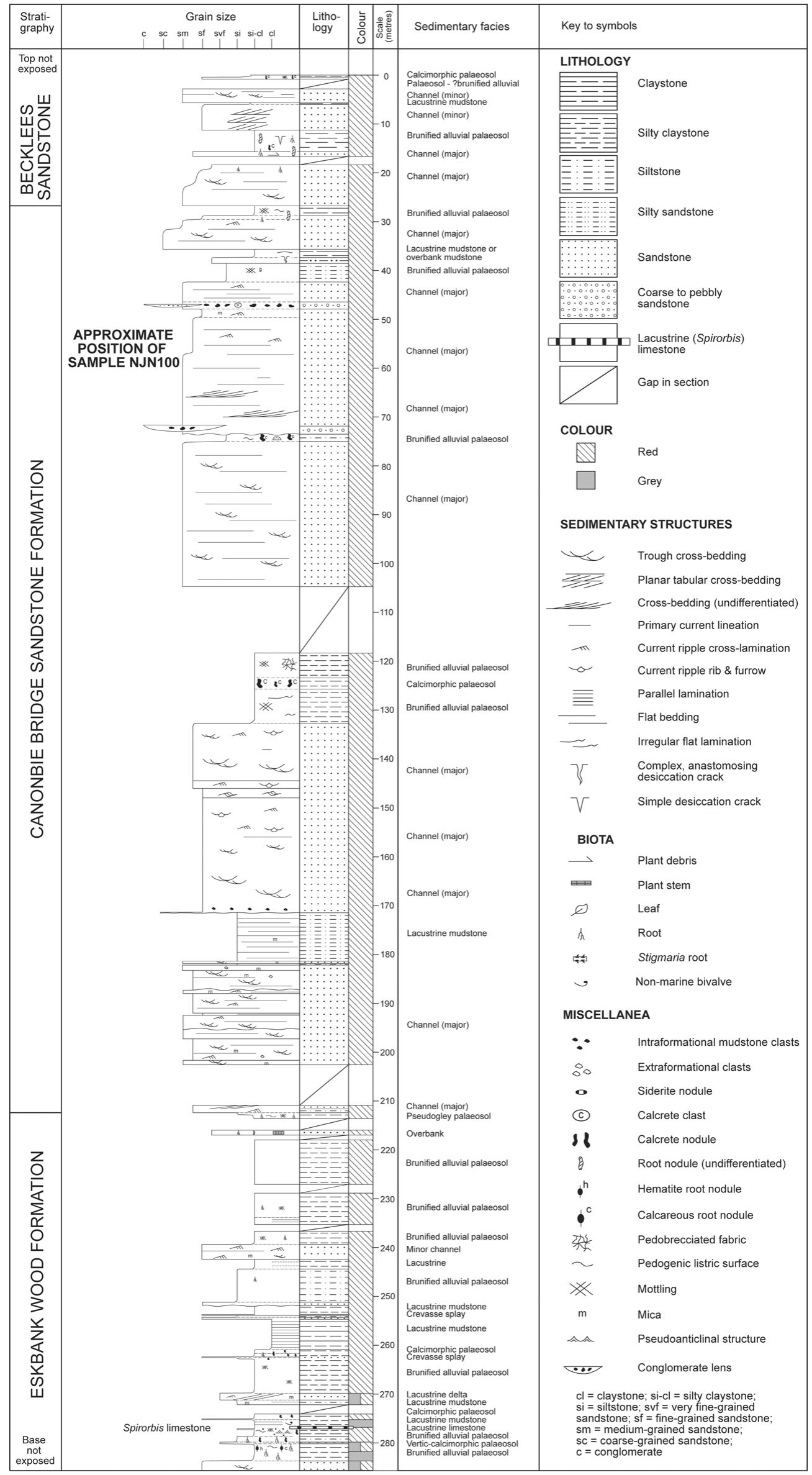

Figure 4. Composite sedimentological log of the Warwickshire Group succession exposed along the River Esk, Canonbie between [3917 7705] and [3930 6726], showing approximate stratigraphical position of sample NJN100 within the Canonbie Bridge Sandstone Formation (modified from Jones, Holliday \& McKervey, 2010). 
multi-storey units. In hand specimen, the sandstones are fine- to medium-grained, orange brown to bright reddish brown and pinkish brown, moderately to well sorted, typically lack mica, and contain low proportions of lithic clasts. At outcrop along the River Esk, the change in lithology between the Canonbie Bridge Sandstone Formation and the Becklees Sandstone Formation is abrupt, and is associated with sand-filled polygonal cracks penetrating the top of the Canonbie Bridge Sandstone Formation. The change in composition, accompanied by a change in palaeocurrent direction from northward-directed in the Canonbie Bridge Sandstone Formation to southerly directed in the Becklees Sandstone Formation, indicates a change in sediment provenance across the boundary. The top of the Becklees Sandstone Formation is truncated at the sub-Permian unconformity and its full thickness is therefore not known, but up to $200 \mathrm{~m}$ was proved in the Becklees Borehole (Jones, Holliday \& McKervey, 2010).

\section{Analytical methods}

Zircon grains were separated from sample NJN100 using standard crushing, washing, heavy liquid (Sp. Gr. 2.96 and 3.3), and paramagnetic procedures. The zircon-rich heavy mineral concentrate was poured onto double-sided adhesive tape, mounted in epoxy together with chips of the reference zircons (TEMORA and SL13), sectioned approximately in half, and polished. Reflected light photomicrographs, transmitted light photomicrographs and cathodoluminescence (CL) scanning electron microscope (SEM) images were prepared for all zircon grains. The CL images were used to decipher the internal structures of the sectioned grains and to ensure that the $\sim 20 \mu \mathrm{m}$ SHRIMP spot was wholly within a single age component within the sectioned grains.

The U-Th- $\mathrm{Pb}$ analyses were made using SHRIMP RG at the Research School of Earth Sciences, The Australian National University, Canberra, Australia. The zircons on the mount were analysed sequentially and randomly until a total of 70 grains was reached. Each analysis consisted of five scans through the mass range, with a reference zircon analysed for every five unknown zircon analyses, following the SHRIMP analytical method recommended by Williams (1998 and references therein). The data have been reduced using the SQUID Excel Macro of Ludwig (2001).

$\mathrm{The} \mathrm{U} / \mathrm{Pb}$ ratios have been normalized relative to a value of 0.0668 for the TEMORA reference zircon, equivalent to an age of $417 \mathrm{Ma}$ (Black et al. 2003). Uncertainties given for individual analyses (ratios and ages) are at the one sigma level (Table A1, in online Appendix at http://www.cambridge.org/journals/geo). Correction for common $\mathrm{Pb}$ was made using the measured ${ }^{204} \mathrm{~Pb} /{ }^{206} \mathrm{~Pb}$ ratio in the normal manner, except for grains younger than $c .800 \mathrm{Ma}$ and for grains with low $\mathrm{U}$ and, therefore, low radiogenic $\mathrm{Pb}$, in which case the ${ }^{207} \mathrm{~Pb}$ correction method was used (Williams,

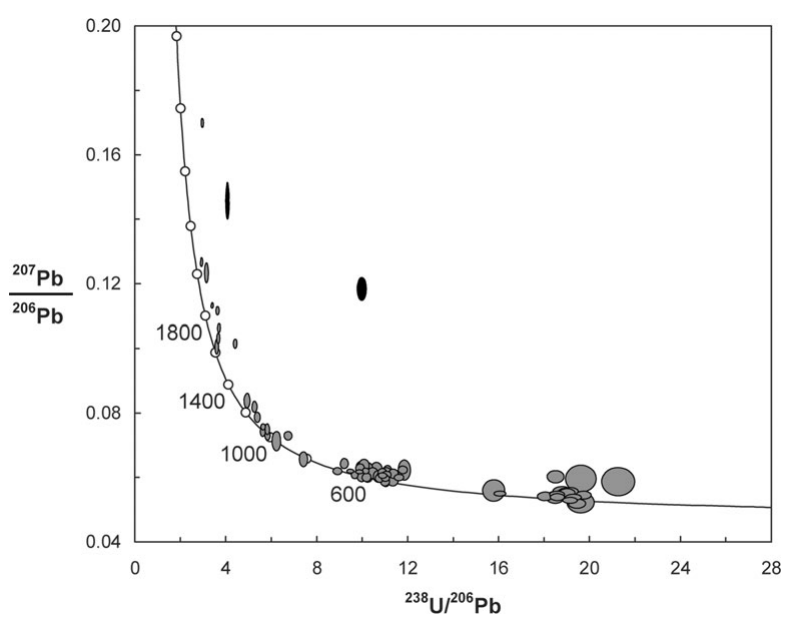

Figure 5. Tera-Wasserburg concordia diagram displaying zircon compositions from Canonbie Bridge Sandstone Formation sample NJN100 $(\mathrm{n}=70)$. Data ellipses are $1 \sigma$. Zircons that are $>20 \%$ discordant or have otherwise unreliable apparent ages are shown in black.

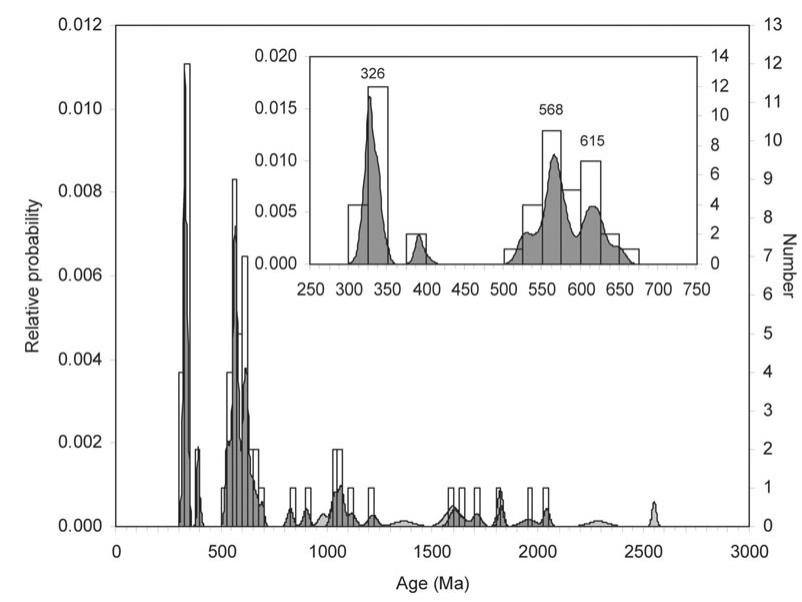

Figure 6. Combined histogram-relative probability plot of zircons from Canonbie Bridge Sandstone Formation sample NJN100 $(\mathrm{n}=69$ of which 63 are $>90 \%$ concordant $)$, generated using the AgeDisplay program (Sircombe, 2004). Inset shows detail of the 250-750 Ma age range and the approximate ages of the main peaks.

1998). When the ${ }^{207} \mathrm{~Pb}$ correction is applied, it is not possible to determine radiogenic ${ }^{207} \mathrm{~Pb} /{ }^{206} \mathrm{~Pb}$ ratios or ages. In general, for areas younger than c. $800 \mathrm{Ma}$, and for areas that are low in $\mathrm{U}$ and therefore low in radiogenic $\mathrm{Pb}$, the radiogenic ${ }^{206} \mathrm{~Pb} /{ }^{238} \mathrm{U}$ age has been used for the histogram and probability density plots. The ${ }^{207} \mathrm{~Pb} /{ }^{206} \mathrm{~Pb}$ age is used for grains older than $800 \mathrm{Ma}$, or for younger grains enriched in $\mathrm{U}$.

\section{Zircon age population in the Canonbie Bridge Sandstone Formation}

The zircon age data from sample NJN100 are displayed on a Tera \& Wasserburg (1972) concordia plot (Fig. 5) generated using Isoplot/Ex (Ludwig, 2003) and on a combined relative probability density-stacked histogram plot (Fig. 6), generated using AgeDisplay (Sircombe, 2004). 
The concordia plot shows that the majority of the zircons analysed are concordant or near-concordant. The most obvious exceptions are grains 16.1 and 31.1, which are $>20 \%$ discordant (Table $\mathrm{A} 1$, in online Appendix at http://www.cambridge.org/journals/geo), and grain 14.1, which lies slightly above concordia, is slightly enriched in common $\mathrm{Pb}$, and yielded a ${ }^{206} \mathrm{~Pb} /{ }^{238} \mathrm{U}$ age close to the Carboniferous-Permian boundary $(294 \pm 7 \mathrm{Ma}, \pm 1 \sigma)$. The Canonbie Bridge Sandstone Formation is believed to be Asturian (equivalent to the Moscovian: Heckel \& Clayton, 2006) in age (Jones, Holliday \& McKervey, 2010), and should therefore be no younger than c. $306.5 \mathrm{Ma}$, according to Gradstein, Ogg \& Smith (2004). Grain 14.1 has an apparent age c. 24 Ma younger than the main Carboniferous group of zircons (Table A1), the youngest of which is $318 \mathrm{Ma}$ (Namurian). This age is therefore considered suspect, and was not plotted on the relative probability density-histogram plot (Fig. 6). It should be noted, however, that it does fall within error of the youngest of the main group of zircons if the appropriate $2 \sigma$ error $( \pm 14 \mathrm{Ma})$ is applied. The grain is probably a Carboniferous zircon that has lost a small amount of radiogenic $\mathrm{Pb}$ from the crystal lattice, causing ${ }^{238} \mathrm{U} /{ }^{206} \mathrm{~Pb}$ to increase, thereby yielding an anomalously young apparent age.

The zircon age spectrum (Fig. 6) shows the presence of two major groups, together with a number of smaller peaks. The two main groups are late Neoproterozoic to early Cambrian (693-523 Ma) and Early Carboniferous (348-318 Ma). The late Neoproterozoic to early Cambrian peak comprises 31 of the 67 concordant or near-concordant grains ( $46 \%$ of the population), and appears to consist of two main groups, the larger one peaking at $c .568 \mathrm{Ma}$ and the smaller one at $c .615 \mathrm{Ma}$. The Early Carboniferous group is represented by 16 zircons ( $24 \%$ of the population), peaking at c. $326 \mathrm{Ma}$. In addition, eight zircons ( $12 \%$ of the population) are late Mesoproterozoic to early Neoproterozoic in age (1119-827 Ma), four (6\%) are late Palaeoproterozoic to early Mesoproterozoic (1712-1566 Ma), and four $(6 \%)$ are mid-Palaeoproterozoic (2042-1818 Ma). Finally, there are two zircons dated at 390-396 Ma, one at $1218 \mathrm{Ma}$, and one at $1365 \mathrm{Ma}$.

Most of the Early Carboniferous zircons are euhedral or subhedral, with simple igneous oscillatory zoning under CL (Fig. 7). Rare grains show more homogeneous CL that may reflect a metamorphic paragenesis. Grains with recognizable cores and overgrowths are scarce. Their habit and zonation patterns suggest that most of the Early Carboniferous zircon grains represent first-cycle derivation from granitoids, which accords with the relatively short time gap between crystallization and sedimentation.

The late Neoproterozoic-early Cambrian zircons show a wider range of habit, from euhedral to rounded. CL images of most grains show zoned igneous internal structures (Fig. 7). A small proportion of late Neoproterozoic-early Cambrian zircons display cores and overgrowths, such as grain 8 (Fig. 7), which

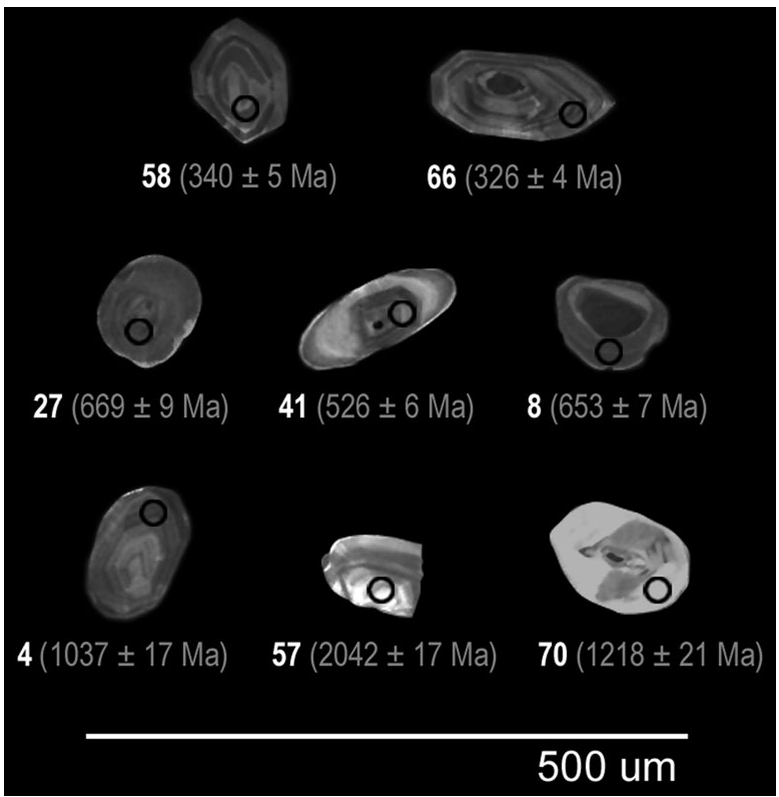

Figure 7. CL images of selected zircon grains from sample NJN100, including: (top row) Early Carboniferous zircons (grains 58 and 66) showing euhedral or near-euhedral habit and intricate igneous zoning; (middle row) late Neoproterozoic to early Cambrian zircons, ranging from rounded grains with diffuse zoning (grain 27), near-euhedral grains with intricate zoning (grain 41), and grains with unzoned cores and intricately zoned igneous overgrowths (grain 8), and (bottom row) Palaeoproterozoic to late Mesoproterozoic zircons, including subrounded grains with intricate zoning (grain 4) and subrounded grains with diffuse zoning (grain 57). Grain 70 has an intricately zoned igneous core and bright, apparently unzoned (possibly metamorphic) overgrowth.

CL shows to have a dark homogeneous core and a weakly zoned igneous overgrowth (the latter dated as $653 \pm 7 \mathrm{Ma})$.

The older (Palaeoproterozoic to early Neoproterozoic) zircon population has few euhedral or neareuhedral grains, most being subrounded, rounded or subangular. It seems likely that many of these older zircons are recycled. Most have igneous zonation patterns (Fig. 7). Some of the Palaeoproterozoic to early Neoproterozoic zircons display cores and overgrowths. One zircon (grain 70) has an irregular intricately zoned igneous core that has been partially resorbed and/or replaced by a bright $\mathrm{CL}$, homogeneous overgrowth (Fig. 7). The overgrowth has comparatively low $U$ (47 ppm) and very low Th (Table A1). The Th/U ratio of $\leq 0.01$, in conjunction with the habit, suggests that the overgrowth may be of metamorphic origin.

\section{Discussion}

The zircon population in sample NJN100 from the Canonbie Bridge Sandstone Formation unequivocally indicates that the sediment was derived from south of the Variscan Front. This is diagnosed by the presence of the two major age groups, Early Carboniferous (348$318 \mathrm{Ma}$ ) and late Neoproterozoic to early Cambrian (693-523 Ma). The Early Carboniferous group 
corresponds to granitoid magmatism and associated metamorphism in Brittany, dated as $345-300 \mathrm{Ma}$ (Brown \& Dallmeyer, 1996), and in the SaxoThuringian Zone of the central European Variscides, which ranges from 352 to $290 \mathrm{Ma}$ (Tischendorf et al. 1995). The late Neoproterozoic to early Cambrian group corresponds to the Cadomian of Armorica (Guerrot \& Peucat, 1990; Strachan, D'Lemos \& Dallmeyer, 1996) and the central European Variscides, such as the Saxo-Thuringian Zone (Tischendorf et al. 1995). Derivation from the north or west can be categorically ruled out, since the zircon age structure in sample NJN100 contrasts strongly with that seen in northerly or westerly derived Carboniferous sandstones in the Pennine Basin. The zircon populations in northerly or westerly derived sandstones have Archaean, mid-Proterozoic and Silurian-Devonian elements, indicating that their source regions lay in parts of Laurentia-Baltica that were affected by the Caledonian orogeny (Hallsworth et al. 2000).

The zircon data therefore indicate that the Canonbie Bridge sandstones represent the products of a river system that drained the Variscan orogenic belt several hundreds of kilometres to the south or southeast, providing strong support for the suggestion made on the basis of petrographical, heavy mineral and palaeocurrent evidence (Jones, Holliday \& McKervey, 2010). The zircon age structure of the Halesowen Formation of the English Midlands, which has similar petrographical and heavy mineral characteristics (Jones, Holliday \& McKervey, 2010), is closely comparable to that seen in sample NJN100 (Fig. 8). The Halesowen zircon age spectrum contains two main groups (357$323 \mathrm{Ma}$ and $651-534 \mathrm{Ma}$ ), comprising $38 \%$ and $33 \%$ of the population, respectively. These peaks directly match the two main peaks in the Canonbie Bridge Sandstone Formation, although the relative abundance of zircons in the two groups is somewhat different. The other components of the Halesowen spectrum also correspond to those present in the Canonbie Bridge Sandstone Formation (Fig. 8). There is little doubt that the Halesowen Formation and the Canonbie Bridge Sandstone Formation share a common provenance, and that their source area lay within the Variscides of western or central Europe.

The Dalton Rock (Bolsovian) near Sheffield, Yorkshire, and the Cleaver Formation (Duckmantian) of the southern North Sea also have zircon age populations diagnosing derivation from the Variscides (Hallsworth et al. 2000; Morton, Hallsworth \& Claoué-Long, 2001; Morton, Hallsworth \& Moscariello, 2005). These sandstones have bimodal zircon populations similar to those in the Canonbie Bridge Sandstone and Halesowen formations (Fig. 8), with Carboniferous and late Neoproterozoic to early Cambrian peaks.

There are two likely sources for these Variscanderived sandstones: the Saxo-Thuringian Zone of central Europe and the Armorican Massif of Brittany. As discussed above, both of these areas have Early Carboniferous granitoids intruding Cadomian crust.

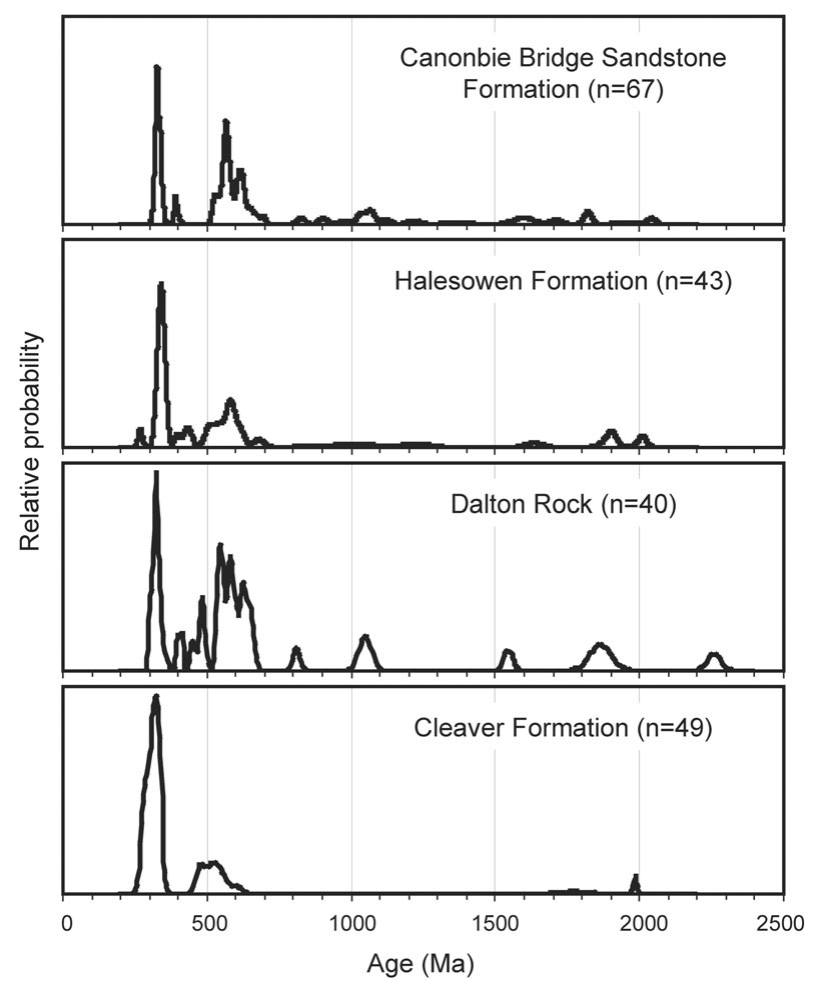

Figure 8. Comparison of detrital zircon age spectra from the Canonbie Bridge Sandstone Formation compared with other Carboniferous sandstones derived from the Variscides, adapted from Hallsworth et al. (2000) and Morton et al. (2001, 2005).

It is unlikely that Armorican-derived sediment could have reached the Pennine Basin and southern North Sea areas during the Duckmantian-Bolsovian, since the Wales-Brabant High was an area of positive relief at that time (Besly, 1988; Cope et al. 1992). Consequently, the Cleaver Formation and Dalton Rock are believed to have been derived from the SaxoThuringian Zone to the southeast (Morton, Hallsworth \& Claoué-Long, 2001; Morton, Hallsworth \& Moscariello, 2005). However, during the Asturian, there is evidence that the Wales-Brabant High was breached (Besly, 1988), a view supported by the similarity between the petrographical character of the Halesowen and Canonbie Bridge Sandstone formations (north of the Wales-Brabant High) and the Pennant Sandstone Formation (south of the high), which suggests a common provenance for these sandstones. Hence, it is possible that sediment could have been introduced to the English Midlands and the Canonbie area from the Armorican Massif through the breached WalesBrabant High at this time (Hallsworth et al. 2000). However, Sherlock, Jones \& Jones (2000) argued that Bolsovian-Asturian lithic arenites in the Forest of Dean Basin (south of the Wales-Brabant High) were derived from the central European Variscides.

There is heavy mineral evidence indicating that the Dalton Rock and similar 'Mexborough-type' sandstones had a different provenance to the Halesowen Formation, the former having higher monazite:zircon (Hallsworth et al. 2000). It could 
be argued, therefore, that the Dalton Rock was derived from a different source to the Halesowen and Canonbie Bridge Sandstone formations (SaxoThuringian as opposed to Armorican). However, it can equally well be argued that the difference in mineralogy represents a change in the nature of the lithologies available for erosion, for example, through uplift. This question therefore remains to be resolved.

The origin of the older Proterozoic zircons in the Canonbie Bridge Sandstone Formation remains somewhat equivocal. They could either represent older crustal components within the Variscides, or be derived from sources outwith the Variscan belt. Most of the peri-Gondwanan terranes in central and western Europe have a Palaeoproterozoic (c. 2.2-2.0 Ga) protolith (Armorica, Saxo-Thuringia, Moldanubia), with only the Moravian-Silesian area having younger (c. 1.3-1.0 Ga) crust (Calvez \& Vidal, 1978; Nance et al. 2008). Hence, the older Palaeoproterozoic zircons in the Canonbie Bridge Sandstone and Halesowen formations, which extend back to $>2.0 \mathrm{Ga}$, could have been derived from the western or central European Variscides. The late Mesoproterozoic to early Neoproterozoic group in the Canonbie Bridge Sandstone Formation is approximately coeval with the so-called 'Pentevrian' event (c. 900-1100 Ma), formerly believed to be the age of the Penthièvre massif in Brittany (Bishop, Roach \& Adams, 1975), but the significance of this event was subsequently called into question by Roach, Lees \& Shufflebotham (1990). High-grade paragneisses in the Mid-German Crystalline Rise (adjacent to the Saxo-Thuringian Zone) contain small numbers of $c .1 .0 \mathrm{Ga}$ zircons in association with dominant c. $550 \mathrm{Ma}$ and c. $2.06 \mathrm{Ga}$ zircons (Zeh et al. 2001). In the Massif Central of France, Visean volcanic rocks contain xenocrystic zircons dated as Mesoproterozoic, $>1.0 \mathrm{Ga}$ (Bruguier et al. 1998), approximately coeval with the late Mesoproterozoic to early Neoproterozoic group in the Canonbie Bridge Sandstone Formation. Therefore, there is evidence to indicate that late Mesoproterozoic to early Neoproterozoic zircons could have been derived from basement rocks in the Variscides. It is also possible that early Neoproterozoic to Palaeoproterozoic zircons could have been recycled from sandstones within the Variscides. For example, Gerdes \& Zeh (2006) and Linnemann et al. (2008) have established that early Neoproterozoic (c. 850 to $1000 \mathrm{Ma}$ ) and Palaeoproterozoic (c. 1700 to $2250 \mathrm{Ma}$ ) zircon age populations are present as detrital components within sandstones of the central European Variscides. Therefore, the only Proterozoic component of the zircon age spectrum that cannot be readily matched with a source in the Variscides is that found at c. $1600 \mathrm{Ma}$. It is also possible to find a Variscan source for the zircons dated as 390-396 Ma, since this corresponds to the subduction-obduction cycle of the Rheic and Galicia-Massif Central Palaeozoic oceans (Matte, 1986); furthermore, grains of this age have been found in the Visean of the Massif Central (Bruguier et al. 1998).

For the most part, therefore, the zircon population in the Canonbie Bridge Sandstone Formation can be matched with sources in the Variscides. However, it is also possible that some detritus was supplied from nonVariscan sources traversed by the river system en route to the Canonbie area. Incorporation of a small amount of older northerly derived Carboniferous (Namurian) sediment is one possibility, since these sandstones contain a wide range of mid-Proterozoic grains in conjunction with Silurian-Devonian (Caledonianage) zircons (Hallsworth et al. 2000). However, this mechanism should also introduce a small number of Archaean zircons, which does not appear to be the case, the only possible exception being grain 15.1 , which yielded an age of $2551 \pm 10$ Ma but is $24 \%$ discordant. Recycling of northerly derived Old Red Sandstone is another possibility, but cannot be tested owing to the absence of zircon age data from the Old Red Sandstone.

\section{Conclusions}

The zircon population in the Late Carboniferous Canonbie Bridge Sandstone Formation comprises two main peaks, one of Early Carboniferous age (348-318 Ma), corresponding to the age of igneous activity during the Variscan Orogeny, and one of late Neoproterozoic to early Cambrian age (693-523 Ma), corresponding to the Cadomian. Together, these two groups comprise $70 \%$ of the zircon population. These data show unequivocally that most of the sediment was derived from the Variscides of western or central Europe. The assemblage also contains a range of older Proterozoic zircons, including a late Mesoproterozoic to early Neoproterozoic group (1119-827 Ma), a late Palaeoproterozoic to early Mesoproterozoic group (1712-1566 Ma), and a mid-Palaeoproterozoic group (2042-1818 Ma), together with two Devonian grains. Most of these zircons can also be attributed to Variscan sourcing, the only exception being the $c$. $1600 \mathrm{Ma}$ group. However, it is also possible that some of the late Mesoproterozoic to Palaeoproterozoic and Devonian zircons were locally derived through recycling of northerly derived sandstones of DevonianCarboniferous age.

The Canonbie Bridge Sandstone Formation zircon population is closely comparable to those found in other Variscan-sourced sandstones from the UK Carboniferous, the coeval (Asturian) Halesowen Formation of the English Midlands, the older Bolsovian Dalton Rock of Yorkshire, and the Duckmantian Cleaver Formation of the southern North Sea, as described by Hallsworth et al. (2000), Morton, Hallsworth \& Claoué-Long (2001) and Morton, Hallsworth \& Moscariello (2005).

The zircon age data confirm previous suggestions of a Variscan source for the Canonbie Bridge Sandstone Formation, made on the basis of petrographical, heavy mineral and palaeocurrent evidence (Jones, Holliday $\&$ McKervey, 2010). This is the most northerly record 
to date of Variscan-derived sediment in the UK, the previous being the Bolsovian Dalton Rock of Yorkshire. However, the sandstones at Canonbie are thick (channels $2-10 \mathrm{~m}$ thick in multi-storey units up to $50 \mathrm{~m}$ thick) and are believed to represent fairly extensive northerly flowing fluvial systems. Given their size, it is thought likely that they would extend to at least the Midland Valley of Scotland, and probably beyond. Similar-aged successions are known locally from the Midland Valley (e.g. the Ayrshire Coalfield) and it is interesting to speculate about the provenance of sandstones in this area.

Possible sources for the Canonbie Bridge Sandstone Formation and coeval Halesowen Formation are the Armorican Massif of Brittany and the Saxo-Thuringian Zone of the central European Variscides. Derivation from the former would require transport across the Wales-Brabant High, which is believed to have been breached by this time (Besly, 1988). The SaxoThuringian Zone is believed to have supplied the earlier Westphalian Variscan-sourced sandstones (Morton, Hallsworth \& Claoué-Long, 2001; Morton, Hallsworth $\&$ Moscariello, 2005), but these have different heavy mineral characteristics to the Asturian (Hallsworth et al. 2000), implying they had a different provenance. However, this could either reflect a geographical shift in source or evolution of the lithological characteristics within the same source area, and cannot be taken as proof of Armorican versus central European sourcing.

Acknowledgements. We are grateful to Doug Holliday for his help and encouragement with this study, to John McKervey for providing the heavy mineral separate, and to Dirk Frei for his helpful comments on a previous version of the manuscript.

\section{References}

BARRETT, B. H. \& RicheY, J. E. 1945. Economic geology of Canonbie Coalfield (Dumfriesshire and Cumberland). Geological Survey of Great Britain Wartime Pamphlet 42, $51 \mathrm{pp}$.

BESLY, B. M. 1988. Palaeogeographic implications of late Westphalian to early Permian red-beds, Central England. In Sedimentation in a synorogenic Basin Complex: the Upper Carboniferous of Northwest Europe (eds B. M. Besly \& G. Kelling), pp. 200-21. Glasgow: Blackie.

Besly, B. M. \& Cleal, C. J. 1997. Upper Carboniferous stratigraphy of the West Midlands (UK) revised in the light of borehole geophysical logs and detrital compositional suites. Geological Journal 32, 85-118.

Bishop, A. C., ROACH, R. A. \& ADAMS, C. J. D. 1975. Precambrian rocks within the Hercynides. In $A$ correlation of Precambrian rocks in the British Isles (eds A. L. Harris, R. M. Shackleton, J. Watson, C. Downie, W. B. Harland \& S. Moorbath), pp. 102-7. Geological Society of London, Special Report no. 6.

Black, L. P., Kamo, S. L., Allen, C. M., Aleinikoff, J. N., DAVIS, D. W., Korsch, R. J. \& Foudoulis, C. 2003. TEMORA 1: a new zircon standard for Phanerozoic U-Pb geochronology. Chemical Geology 200, 155-70.
British Geological SurVey. 1999. Coal Resources Map of Britain (coodinator G. R. Chapman). NERC and the Coal Authority.

Brown, M. \& DAllmeYeR, R. D. 1996. Rapid Variscan exhumation and the role of magma in core complex formation: southern Brittany metamorphic belt, France. Journal of Metamorphic Geology 14, 361-79.

Bruguier, O., BecQ-Giraudon, J. F., Bosch, D. \& LANCELOT, J. R. 1998. Late Visean hidden basins in the internal zones of the Variscan belt: U-Pb zircon evidence from the French Massif Central. Geology 26, 627-30.

CALVEZ, J. Y. \& VIDAL, P. 1978. Two billion year old relicts in the Hercynian Belt of western Europe. Contributions to Mineralogy and Petrology 65, 395-9.

Cope, J. C. W., Guion, P. D., Sevastopulo, G. D. \& Swan, A. R. H. 1992. Carboniferous. In Atlas of Palaeogeography and Lithofacies (eds J. C. W. Cope, J. K. Ingham \& P. F. Rawson), pp. 67-86. Geological Society of London, Memoir no. 13.

DAY, J. B. W. 1970. Geology of the country around Bewcastle. Memoirs of the Geological Survey of Great Britain England and Wales. London: Her Majesty's Stationery Office, $357 \mathrm{pp}$.

Gerdes, A. \& ZEH, A. 2006. Combined U-Pb and Hf isotope LA-(MC-) ICP-MS analyses of detrital zircons: comparison with SHRIMP and new constraints for the provenance and age of an Armorican metasediment in Central Germany. Earth and Planetary Science Letters 249, 47-62.

Gradstein, F. M., OgG, J. G. \& Smith, A. G. 2004. A Geologic Time Scale 2004. Cambridge: Cambridge University Press, 589 pp.

Guerrot, C. \& Peucat, J. J. 1990. U-Pb geochronology of the Upper Proterozoic Cadomian orogeny in the northern Armorican Massif, France. In The Cadomian orogeny (eds R. S. D’Lemos, R. A. Strachan \& C. G. Topley), pp. 13-26. Geological Society of London, Special Publication no. 51.

Hallsworth, C. R., Morton, A. C., Claoué-Long, J. \& FANNING, C. M. 2000. Carboniferous sand provenance in the Pennine Basin, UK: constraints from heavy mineral and detrital zircon age data. Sedimentary Geology 137, $147-85$.

Heckel, P. H. \& Clayton, G. 2006. The Carboniferous System. Use of the new official names for the subsystems, series, and stages. Geologica Acta 4, 403-7.

Jones, N. S., Holliday, D. W. \& McKervey, J. A. 2010. Warwickshire Group (Pennsylvanian) red-beds of the Canonbie Coalfield, England-Scotland border, and their regional palaeogeographical implications. Geological Magazine, in press.

Linnemann, U., Pereira, F., JefFries, T. E., Drost, K. \& GERDES, A. 2008. The Cadomian Orogeny and the opening of the Rheic Ocean: the diachrony of geotectonic processes constrained by LA-ICP-MS U$\mathrm{Pb}$ zircon dating (Ossa-Morena and Saxo-Thuringian Zones, Iberian and Bohemian Massifs). Tectonophysics 461, 21-43.

LudwIG, K. R. 2001. SQUID 1.02, A User's Manual. Berkeley Geochronology Center Special Publication no. 2.

LudWIG, K. R. 2003. Isoplot/Ex version 3.0: A geochronological toolkit for Microsoft Excel. Berkeley Geochronology Center Special Publication no. 4.

Lumsden, G. I., Tulloch, W., Howells, M. F. \& DAVIES, A. 1967. The geology of the neighbourhood of Langholm. 
Memoir of the Geological Survey of Great Britain, $255 \mathrm{pp}$

MATTE, P. 1986. Tectonics and plate tectonics model for the Variscan belt of Europe. Tectonophysics 126, 329-74.

Morton, A. C., Hallsworth, C. R. \& Claoué-Long, J. C. 2001. Zircon age and heavy mineral constraints on provenance of North Sea Carboniferous sandstones. Marine and Petroleum Geology 18, 319-37.

Morton, A. C., Hallsworth, C. R. \& Moscariello, A. 2005. Interplay between northern and southern sediment sources during Westphalian deposition in the Silverpit Basin, southern North Sea. In Carboniferous hydrocarbon geology: the southern North Sea and surrounding onshore areas (eds J. D. Collinson, D. J. Evans, D. S. Holliday \& N. S. Jones), pp. 135-46. Yorkshire Geological Society Occasional Publication no. 7.

Nance, R. D., Murphy, J. B., Strachan, R. A., Keppie, J. D., Gutierrez-Alonso, G., Fernandez-Suarez, J., Quesada, C., Linnemann, U., D’Lemos, R. \& PISAREVSKY, S. A. 2008. Neoproterozoic-early Palaeozoic tectonostratigraphy and palaeogeography of the peri-Gondwanan terranes: Amazonian v. West African connections. In The boundaries of the West African Craton (eds N. Ennih \& J.-P. Liégeois), pp. 345-83. Geological Society of London, Special Publication no. 297.

Peach, B. N. \& Horne, J. 1903. The Canonbie Coalfield: its geological structure and relations to the Carboniferous rocks of northern England and central Scotland. Transactions of the Royal Society of Edinburgh 40, 835-77.

PICKEN, G. S. 1988. The concealed coalfield at Canonbie: an interpretation based on boreholes and seismic surveys. Scottish Journal of Geology 24, 61-71.

Powell, J. H., Chisholm, J. I., BRIDGe, D. MCC., Rees, J. G., Glover, B. W. \& Besly, B. M. 2000. Stratigraphical framework for Westphalian to Early Permian red-bed successions of the Pennine Basin. British Geological Survey Research Report RR/00/01.

Ramsbottom, W. H. C., CAlver, M. A., EAger, R. M. C., Hodson, F., Holliday, D. W., Stubblefield, C. J. \& WILSON, R. B. 1978. A correlation of Silesian rocks in the British Isles. Geological Society of London, Special Report no. 10, $81 \mathrm{pp}$.

Roach, R. A., Lees, G. J. \& Shufflebotham, M. M. 1990. Brioverian volcanism and Cadomian tectonics, Baie de St Brieuc, Brittany: stages in the evolution of a late Precambrian ensialic basin. In The Cadomian orogeny (eds R. S. D'Lemos, R. A. Strachan \& C. G. Topley), pp. 41-67. Geological Society of London, Special Publication no. 51.
SHerlock, S. C., JoneS, K. A. \& JONES, J. A. 2000. A central European Variscide source for Upper Carboniferous sediments in SW England: ${ }^{40} \mathrm{Ar} /{ }^{39} \mathrm{Ar}$ detrital white mica ages from the Forest of Dean. Journal of the Geological Society, London 157, 905-8.

Simpson, J. B. \& RiCHEY, J. E. 1936. The geology of the Sanquhar Coalfield. Memoirs of the Geological Survey of Scotland, $97 \mathrm{pp}$.

SircomBe, K. N. 2004. Age Display: an excel workbook to evaluate and display univariate geochronological data using binned frequency histograms and probability density distributions. Computers and Geosciences 30, 21-31.

Strachan, R. A., D'Lemos, R. S. \& Dallmeyer, R. D. 1996. Neoproterozoic evolution of an active margin: North Armorican Massif, France. In Avalonian and Related Perigondwanan Terranes of the Circum-North Atlantic (eds R. D. Nance \& M. D. Thompson), pp. 319-32. Geological Society of America, Special Paper no. 304.

Tera, F. \& WasserburG, G. 1972. U-Th-Pb systematics in three Apollo 14 basalts and the problem of initial $\mathrm{Pb}$ in lunar rocks. Earth and Planetary Science Letters 14, 281-304.

Tischendorf, G., FÖrster, H.-J., FrischbutTER, A., Kramer, W., SCHMidT, W. \& Werner, C. D. 1995. Igneous activity. In Pre-Permian Geology of Central and Eastern Europe (eds R. D. Dallmeyer, W. Franke \& K. Weber), pp. 249-59. Berlin: Springer-Verlag.

TROTTER, F. M. 1953. Reddened beds of Carboniferous age in North-West England and their origin. Proceedings of the Yorkshire Geological Society 29, 1-20.

Trueman, A. E. \& WeIR, J. 1946-58. A monograph on British Carboniferous non-marine Lamellibranchia. Palaeontographical Society Monograph, 449 pp.

Waters, C. N., Browne, M. A. E., DeAn, M. T. \& POWELL, J. H. 2007. Lithostratigraphical framework for Carboniferous successions of Great Britain (onshore). British Geological Survey Research Report RR/ 07/01.

WiLLIAMS, I. S. 1998. U-Th-Pb geochronology by ion microprobe. In Applications of microanalytical techniques to understanding mineralizing processes (eds M. A. McKibben, W. C. Shanks III \& W. I. Ridley), pp. 135. Reviews in Economic Geology 7.

ZeH, A., BrätZ, H., Miller, I. L. \& Williams, I. S. 2001. A combined zircon SHRIMP and Sm-Nd isotope study of high-grade paragneisses from the Mid-German Crystalline Rise: evidence for northern Gondwanan and Grenvillian provenance. Journal of the Geological Society, London 158, 983-94. 